\title{
ERRATA
}

\section{Biotic and Abiotic Factors Affecting Plasmid Transfer in Escherichia coli Strains}

\author{
AURORA FERNANDEZ-ASTORGA, ALICIA MUELA, RAMÓN CISTERNA,
} JUAN IRIBERRI, AND ISABEL BARCINA

Departamento de Microbiología e Inmunología, Facultad de Farmacia, Apdo. 450, Universidad del País Vasco, E-01080 Vitoria, and Facultad de Ciencias, Apdo. 644, and Facultad de Medicina, Apdo. 699, Universidad del País Vasco, E-48080 Bilbao, Spain

Volume 58, no. 1, p. 393, column 1, line 9: "mid-log phase" should read "early stationary phase."

\section{Comparative Study of 35 Bacteriophages of Lactobacillus helveticus: Morphology and Host Range \\ LAURENT SÉCHAUD, MICHELINE ROUSSEAU, BLANDINE FAYARD, MARIA LUISA CALLEGARI, PASCAL QUÉNÉE, AND JEAN-PIERRE ACCOLAS \\ Station de Recherches Laitières, Institut National de la Recherche Agronomique, 78350 Jouy-en-Josas, France}

Volume 58, no. 3, p. 1015, column 1, lines 43 to 47: these sentences should read as follows. "Twenty-five colonies per culture (i.e., a total of 125 clones) were picked up and transferred to $1 \mathrm{ml}$ of MRS broth (diluted 1/10) with $20 \%$ (vol/vol) glycerol and antiphage 0241 serum (final dilution, $10^{-3}$ ) and frozen at $-20^{\circ} \mathrm{C}$. When necessary, bacterial suspensions were rapidly thawed and reisolated by streaking on MRS agar. Isolated clones were grown with $0.1 \mu \mathrm{g}$ of $\mathrm{MC}$ per ml for $5 \mathrm{~h}$ and centrifuged. The supernatants were then tested for plaque assay on indicator strain CNRZ 892 in order to detect the lack of induced phage particles. Only one of the 125 isolates was found to be negative. This clone was also sensitive to temperate phage 0241."

\section{Styrene Formation by the Decomposition by Pichia carsonii of trans-Cinnamic Acid Added to a Ground Fish Product KUNIO SHIMADA, EIJI KIMURA, YOHKO YASUI, HIDEKI TANAKA, SUMIO MATSUSHITA, HIROSHI HAGIHARA, MASATOSHI NAGAKURA, AND MICHITAKA KAWAHISA}

Division of Microbiology and Division of Food and Drug Chemistry, Hyogo Prefectural Institute of Public Health, 2-1-29 Arata-cho, Hyogo-ku, Kobe 652, Hyogo Prefectural Itami Health Center, 1-51 Senzo, Itami 664, and Department of Public Health and Environment, Hyogo Prefectural Office, 5-10-1 Shimoyamate, Chuo-ku, Kobe 650, Japan

Volume 58, no. 5, p. 1580, column 2, last line: “cinnamic acid production" should read "styrene production." 